\title{
The Employees Perception of Food Safety Practices in select food companies
}

\author{
G. Ramu1; Prof. D. Sreeramulu²; Dr. Rambabu Lavuri ${ }^{3}$ \\ ${ }^{1}$ Research scholar, Osmania University College of Management. Email: golla.ramu@gmail.com \\ ${ }^{2}$ Dean Faculty of Management, Osmania University, Hyderabad, Telengana, India. Email: profsreeramulu@gmail.com \\ ${ }^{3}$ Post Doctoral fellow, Osmania University College of Management.Email: rambabu.lavuri@gmail.com
}

\begin{abstract}
The employee's perceptions of hedges to implementing food safety practices in select food companies. The research study is focused on six food safety dimensions for easy to assessment of food problems and implementing food safety practices in select food companies. The six dimensions are related to food safety the respondent's questionnaire were received from 520 employees are working in four food companies. The food safety dimensions are classified that employees demographics profile, Food safety Methods, Quality Assurance, Hygienic, Pest Control, Quality Control. As per the dimensions food companies are following food safety methods. The food companies adopted advance technology for cleaning and Hygienic maintenance, sanitation technology for surfaces cleaning work. The main sources of knowledge regarding food safety were educational training and equipment training which help for food manufacturing with safety making of products and high quality with low cost. Food safety practice is an important Public Health issue to prevent or control food-borne illnesses. The governments all over the world are intensifying their efforts to improve food safety. The food safety is usually managed through regulation, Quality Assurance and Hazard Analysis Control Critical Point, Good Manufacture Practice, Quality Mmanagement System, Global Food Safety Initiatives, International Organization for standards 22000 , these are internationally recognized logical tools for adapting traditional inspection methods to modern methods. The Prevention of Food Adulteration Act was introduced by the Government of India in1954. It was replaced by the FSSAI in 2011. According to this act, Food protection from contamination that may lead to the health risk of consumer.
\end{abstract}

\section{INTRODUCTION OF THE FOOD SAFETY PRACTICES}

The Food is fuel for human body. It is essential for growth and maintain the proper health, food give necessary requirements for an human body, it provide energy and maintain body system. Most of the people obtained food from agriculture sector. According to world population growth, it is impossible to have adequate food supply. The food companies are playing a significant role to solve the problem.

The Demand for the food and customer satisfaction, health point of view, the food companies are making safety foods. The most important quality parameter within the food sector is food safety. The development of food processing technologies, applied latest quality control analytical methods. The Food safety means it give assurance that food products are safe to eat to the consumers. It means taking care with all aspects of food production and preparation to make sure that final food product is safe without any contamination. The food safety is usually managed through safety standards and regulation.

The Food safety logical tools are proved to be very effective tool to safety parameter in food processing sector. Based on the observation of the thesis carried out the fallowing conclusion are made that the raw material management and final product management enhance the safety. The Quality Control Lab before they are sent for proximate analysis of raw material and final food products. The Food Safety practices looks for hazards and check every critical control point if anything that could go wrong regarding product safety and implements controls immediately take necessary 
actions for that subsequently to ensure that product will not cause harm to the consumer. The Food safety system mainly focuses on identifying and preventing hazards. The Food safety methods are more efficient and effective in companies oversight and places more responsibility for assure safe food to customers. The select food companies are making biscuits. It is using compete effectively in the world market by reducing barriers to international trade.

\section{MATERIALS AND METHODS}

The study was performed in four biscuit manufacturing companies which are private limited food companies in Hyderabad, Telangana state. The employees are working total population 3800 in four food companies for three shifts to produce the biscuits and cookies. The respondent total 520 employees are taken from the total population. The simple random sampling method is using for selection of sample size from total population. Sampling size selection model based on the formula of Cochran.

The biscuit companies are following the food safety standards and guidelines as per the government rules and regulations. The select food companies are following below food safety standards

1. BRC (British Retail Consortium),

2. HACCP (Hazard Analysis Critical Control Points),

3. Agricultural and processed Food Products Export Development Authority APEDA),

4.ISO 22000 Certified

5. FSSAI.

\section{DATA ANALYSIS AND INTERPRETATION}

This study presents the results of the data analysis of the responses obtained from the employees from the select food companies in Hyderabad, Telangana state. The study presents Descriptive statistical analysis, Chi-Square Analysis and ANOVA Analysis with respect qualitative data analysis is describe in the details. The data analysis has done with the main objectives of finding out the factors, particularly Food Company's employee's data qualitative analysis. The Data analysis is a process of allowing to collected data, analysis of data significance and determination of finding and conclusions. The data analysis helps in finding conclusions and results helps with help of scientific methods. The significance of the data analysis is to provide suitable findings for proper results and conclusions. The data collected and coding of data is done with suitable software like SPSS version.23. The data collected by several respondents of select food companies with help of questionnaires.

- Null Hypothesis: Demographic variable of Respondents does not influence the food safety Practices.

- Alternative Hypothesis: Demographic variable of Respondents influence the food safety Practices.

\begin{tabular}{|c|c|c|c|}
\hline \multicolumn{4}{|c|}{ Table 1. Chi-Square demographics variables wise Respondents } \\
\hline & Value & $\mathrm{df}$ & Asymptotic Significance (2-sided) \\
\hline Pearson Chi-Square & $205.457^{\mathrm{a}}$ & 45 & .000 \\
\hline Likelihood Ratio & 230.275 & 45 & .000 \\
\hline Linear-by-Linear Association & 45.062 & 1 & .000 \\
\hline N of Valid Cases & 520 & & \\
\hline \multicolumn{2}{|c|}{ a. 24 cells (37.5\%) have expected count less than 5. The minimum expected count is .25. } \\
\hline
\end{tabular}

The table described that the relationship between the education of the Respondents and their Food safety practices. This analysis concludes that result found is 205.457, the significant difference (P value) is 0.00.It is found that significant difference ( $\mathrm{P}$ value) less than 0.05.As per the table indicate that Null hypothesis is rejected and Alternative Hypothesis is accepted. Hence, it is concluded that the demographic variables of Respondents influences the Food safety Practices. 
Null Hypothesis: Demographic variable of Respondents does not influence the food safety Practices.

Alternative Hypothesis: Demographic variable of Respondents influence the food safety Practices.

\begin{tabular}{|c|c|c|c|c|c|}
\hline \multicolumn{7}{|c|}{ Table 2. ANOVA Results } \\
\hline & Sum of Squares & df & Mean Square & F & Sig. \\
\hline Between Groups & 8.439 & 3 & 2.813 & 16.598 & .000 \\
\hline Within Groups & 87.448 & 516 & .169 & & \\
\hline Total & 95.887 & 519 & & & \\
\hline
\end{tabular}

The table described that the relationship between the education of the Respondents and their Food safety practices. This analysis concludes that result found $\mathrm{F}$ value is 16.598 , the significant difference ( $\mathrm{P}$ value) is 0.000 . It is found that significant difference ( $\mathrm{P}$ value) less than 0.05. As per the table indicate that Null hypothesis is rejected and Alternative Hypothesis is accepted. Hence, it is concluded that the demographic variables of Respondents influences the Food safety Practices.

Null Hypothesis: Food Safety Methods of Respondents does not influence food safety Practices.

Alternative Hypothesis: Food Safety Methods of Respondents influence food safety Practices.

\begin{tabular}{|c|c|c|c|}
\hline \multicolumn{3}{|c|}{ Table 3. Chi-Square Test Statistics } \\
\hline & Value & df & Asymptotic Significance (2-sided) \\
\hline Pearson Chi-Square & $523.250^{\mathrm{a}}$ & 6 & .000 \\
\hline Likelihood Ratio & 579.738 & 6 & .000 \\
\hline "Linear-by-Linear Association" & 27.576 & 1 & .000 \\
\hline N of Valid Cases & 520 & & \\
\hline
\end{tabular}

Table described that the connection with Food Safety Methods and safety practices. This analysis concludes that the Pearson found is 523.250, the significant value ( $\mathrm{P}$ value) obtained 0.000 . It is obtained significant value ( $\mathrm{P}$ value) below 0.05 . As per the results from the table indicate that the rejected Null hypothesis, accepted the Alternative Hypothesis. It results that the Food Safety Practices influence by Food Safety Methods of Respondents.

Null Hypothesis: Food safety methods of Respondents do not influence the food safety practices.

Alternative Hypothesis: Food safety methods of Respondents influence food safety Practices

\begin{tabular}{|c|c|c|c|c|c|}
\hline \multicolumn{5}{|c|}{ Table 4. ANOVA results } \\
\hline Between Groups & Sum of Squares & df & Mean Square & F & Sig. \\
\hline Within Groups & 3.962 & 3 & 1.321 & 2458.159 & .000 \\
\hline Total & .277 & 516 & .001 & & \\
\hline
\end{tabular}

Table described that the connection with the education of the Respondents and their Food safety practices. This analysis indicates that the result found is 2458.159 , the significant value (P value) obtained 0.000 . It is found that a significant value (P value) below 0.05 . As per the table indicate that the rejected Null hypothesis, accepted the Alternative Hypothesis. It results that the Food Safety Practices influence by Food Safety Methods of Respondents. It helps to get better the quality of the food products. Quality control methods cover food company certification. Food safety standard methods, raw material checking and packaging material checking, final product inspection, etc

Null Hypothesis: Quality Assurance of Respondents does not influence food safety Practices.

Alternative Hypothesis: Quality Assurance of Respondents influence food safety Practices. 


\begin{tabular}{|c|c|c|c|}
\hline \multicolumn{4}{|c|}{ Table 5. Chi square Test Statistics } \\
\hline & Value & df & Asymptotic Significance (2-sided) \\
\hline Pearson Chi-Square & $30.810 \mathrm{a}$ & 57 & .000 \\
\hline Likelihood Ratio & 32.475 & 57 & .000 \\
\hline "Linear-by-Linear Association" & .705 & 1 & .000 \\
\hline N of Valid Cases & 520 & & \\
\hline
\end{tabular}

Table described that the connection with Quality Assurance of the Respondents their Food safety practices. This analysis concludes that the Chi-Square result is 30.810 , the significant value ( $\mathrm{P}$ value) obtained 0.000 . It is found that a significant value ( $\mathrm{P}$ value) below 0.05 . The findings showed that the null hypothesis was firmly denied and the alternative hypothesis accepted. It concluded that food safety Practices influence by Quality Assurance as per intension of Respondents.

Null Hypothesis: Quality Assurance of Respondents did not influence the food safety Practices

Alternative Hypothesis: Quality Assurance of Respondents influence the food safety Practices.

\begin{tabular}{|c|c|c|c|c|c|}
\hline \multicolumn{7}{|c|}{ Table 6. ANOVA Test Statistics } \\
\hline & Sum of Squares & df & Mean Square & F & Sig. \\
\hline Between Groups & .062 & 3 & .021 & .283 & .000 \\
\hline Within Groups & 37.723 & 516 & .073 & & \\
\hline Total & 37.785 & 519 & & & \\
\hline
\end{tabular}

Table described that the relationship between the Quality Assurance of the Respondents and their Food safety practices. This analysis concludes that the result found is 0.283 , the significant value (P value) obtained 0.000 . It is found that a significant value ( $\mathrm{P}$ value) below 0.05 . As per the table indicate that the rejected Null hypothesis, accepted Alternative Hypothesis. It concluded that food safety Practices influence by Quality Assurance as per intension of Respondents. It helps to enhance the food quality of the food products.

Null Hypothesis: Hygienic of Respondents does not influence the food safety Practices.

Alternative Hypothesis: Hygienic of Respondents influence food safety Practices.

\begin{tabular}{|c|c|c|c|}
\hline & Table 7. Chi-Square Test Statistics & Asymptotic Significance \\
\hline & Value & df & .000 \\
\hline Pearson Chi-Square & $5.496^{\mathrm{a}}$ & 21 & .000 \\
\hline "Likelihood Ratio" & 5.426 & 21 & .000 \\
\hline "Linear-by-Linear Association" & .866 & 1 & \\
\hline
\end{tabular}

Table described that correlation with Hygienic of the Respondents and their Food safety practices. This analysis concludes that the found value is 5.496, the significant difference value ( $\mathrm{P}$ value) obtained 0.000 . It is found that a significant ( $\mathrm{P}$ value) below 0.05 . The findings showed that the null hypothesis was firmly denied and the alternative hypothesis accepted. It concluded that food safety Practices influence by Hygienic as per intension of Respondents.

Null Hypothesis: Hygienic of Respondents does not influence the food safety Practices.

Alternative Hypothesis: Hygienic of Respondents influence food safety Practices.

\begin{tabular}{|c|c|c|c|c|c|}
\hline \multicolumn{7}{|c|}{ Table 8. ANOVA Test Statistics } \\
\hline & Sum of Squares & df & Mean Square & F & Sig. \\
\hline Between Groups & .113 & 3 & .038 & .329 & .000 \\
\hline Within Groups & 58.913 & 516 & .114 & & \\
\hline Total & 59.026 & 519 & & & \\
\hline
\end{tabular}


Table described that the relationship between the Hygienic of the Respondents and their Food safety practices. This analysis concludes that the result found is 0.329 , the significant value ( $\mathrm{P}$ value) obtained 0.000 . It is found that a significant value (P value) below 0.05 . The findings showed that the null hypothesis was firmly denied and the alternative hypothesis accepted. It concluded that food safety Practices influence by Hygienic as per intension of Respondents. It helps to enhance the food quality of the products.

Null Hypothesis: Pest Control of Respondents does not influence food safety Practices.

Alternative Hypothesis: Pest Control of Respondents influence food safety Practices.

\begin{tabular}{|c|c|c|c|}
\hline & Table 9. Chi-Square Test Statistics & Asymptotic Significance \\
\hline & Value & df & .000 \\
\hline "Pearson Chi-Square" & $2.939^{\mathrm{a}}$ & 21 & .000 \\
\hline Likelihood Ratio & 2.892 & 21 & .000 \\
\hline "Linear-by-Linear Association" & 1.250 & 1 & \\
\hline
\end{tabular}

Table described that the relationship between the Pest Control of the Respondents and their Food safety practices. This analysis concludes that the Chi-Square result is 5.496, the significant value (P value) obtained 0.000 . It is found that a significant value (P value) below 0.05 . The findings showed that the null hypothesis was firmly denied and the alternative hypothesis accepted. It concluded that food safety Practices influence by pest control as per intension of Respondents.

Null Hypothesis: Pest Control of Respondents does not influence food safety Practices.

Alternative Hypothesis: Pest Control of Respondents influence food safety Practices.

\begin{tabular}{|c|c|c|c|c|c|}
\hline \multicolumn{5}{|c|}{ Table 10. ANOVA Test Statistics } \\
\hline Between Groups & Sum of Squares & $\mathrm{df}$ & Mean Square & F & Sig. \\
\hline Within Groups & .152 & 3 & .051 & .454 & .000 \\
\hline Total & 57.490 & 516 & .111 & & \\
\hline
\end{tabular}

Table described that the relationship between the Pest Control of the Respondents and their Food safety practices. This analysis concludes that the result found $\mathrm{F}$ value is 0.454 , the significant ( $\mathrm{P}$ value) obtained 0.000 . It is found that a significant value (P value) below 0.05 . As per the table indicate that the rejected Null hypothesis, accepted Alternative Hypothesis. It concluded that food safety Practices influence by pest control as per intension of Respondents. It helps to improve the quality of the food products.

Null Hypothesis: The Quality Control of Respondents does not influence food safety Practices.

Alternative Hypothesis: The Quality Control of Respondents influence food safety Practices.

\begin{tabular}{|c|c|c|c|}
\hline \multicolumn{4}{|c|}{ Table 11. Chi-square Test Statistics } \\
\hline & Value & $\mathrm{df}$ & Asymptotic Significance \\
\hline Pearson Chi-Square & $2.371^{\mathrm{a}}$ & 21 & .000 \\
\hline Likelihood Ratio & 2.330 & 21 & .000 \\
\hline "Linear-by-Linear Association" & .424 & 1 & .000 \\
\hline N of Valid Cases & 520 & & \\
\hline
\end{tabular}

Table described that the connection with the Quality Control of and Food safety practices. This analysis concludes that the Chi-Square result is 2.371 , the significant value ( $\mathrm{P}$ value) obtained 0.000 . It is found that a significant value (P value) below 0.05 . The findings showed that the null hypothesis was firmly denied and the alternative hypothesis accepted. It concluded that food safety Practices influence by Quality Control as per intension of Respondents. 
Null Hypothesis: The Quality Control of Respondents does not influence food safety Practices. Alternative Hypothesis: The Quality Control of Respondents influence food safety Practices.

\begin{tabular}{|c|c|c|c|c|c|}
\hline \multicolumn{7}{|c|}{ Table 12. ANOVA Test Statistics } \\
\hline Between Groups & Sum of Squares & $\mathrm{df}$ & Mean Square & F & Sig. \\
\hline Within Groups & .063 & 3 & .021 & .261 & .000 \\
\hline Total & 41.745 & 516 & .081 & & \\
\hline
\end{tabular}

Table described that the connection with the Quality Control and Food safety practices. This analysis concludes that the result found is 0.261 , the significant difference ( $\mathrm{P}$ value) obtained 0.000 . It is found that a significant ( $\mathrm{P}$ value) below 0.05. As per the table indicate that the rejected Null hypothesis, accepted the Alternative Hypothesis. It concluded that food safety Practices influence by Quality Control as per intension of Respondents. It helps to enhance the food safety of the food products.

\section{CONCLUSIONS}

The study concluded that the employee's response on food safety practices in select food companies. It adopted the food safety standards and regulations like FSSAI and HACCP, ISO22000:2005, BRC, APEDA. The reasonable partnership between the Indigenous Food Safety Standard Authority and other international bodies that ensure food safety and food law standards. The roles of food safety standards must be considered within the circumstance of inspections are carried out from companies. Inspection from the raw material to the finished product allowing process run. As the study is limited to four food companies which is located at Hyderabad, Telanagna foods.

The select food companies have produced biscuits and cookies ensure crispiness and high quality which is more acceptable. The biscuits are considered as a snack there contain crispiness contain product and manufacturing so many types of variety biscuits. All the raw materials and packaging material analysed in the Quality Control laboratory before they are sent to processing. It has given chance for employees for active participation with training and also improved their knowledge in fields of food processing. The companies are producing high protein and calorie supplement products to children and all age group people. The select food companies are following the food safety standard and guidelines, as per records dates conducting internal and external audits, providing suitable training for employees, the companies overall food safety practices satisfied with the export quality of food products. The select food companies data analysis was concluded that respondent perception on food safety practices influence to six dimensions like employees demographic variable, Food safety Methods, Quality Assurance, Hygienic, Pest Control, Quality Control, as per research study select food companies are following suitable food safety standards and making safety products.

\section{REFERENCES}

1. Anna M. Lammerding. (1997). An Overview of Microbial Food Safety Risk Assessment. Journal of Food Protection: November 1997, Vol. 60, No. 11, pp. 1420-1425.

2. Carl A. Batt. (2016). Food Safety Hazard, Chemical and Physical Hazards in Food, eBook ISBN: 9780123847331 , Imprint: Academic Press, Published Date: 2nd April 2016.

3. Constantina Tzia, Theodoros Varzakas. (2015). Handbook of Food Processing: Food Safety, Quality, and Manufacturing Processes, Originally: 21 October 2015.Publisher: CRC Press, ISBN-s: 149872177X / 9781498721776,1498721788 / 9781498721783.

4. Constantina Tzia, TheodorosVarzakas.(2015).Handbook of Food Processing: Food Safety, Quality, and Manufacturing Processes, Originally published: 21 October 2015.Publisher: CRC Press,ISBN-s: 149872177X / $9781498721776,1498721788 / 9781498721783$. 
5. David McSwane, Nancy R. Rue, Richard Linton :Essentials of Food Safety And Sanitation Study Guide,

6. Copyright 1997,Published by Prentice Hall, ISBN 10: 0131197789 ISBN 13: 9780131197787.

7. Debby Newslow.(2016).Food Safety Management Programs 1st Edition, Publisher: Routledge;1 edition (October 14, 2016),ISBN-10: 1138198463,ISBN-13: 978-1138198463.

8. Dr. Kelly S. Meier.(2018). About Food Safety Sanitation Management." Work - Chron.com, http://work.chron. com/food-safety-sanitation-management-23195.html. 24 August 2018.

9. G. Subbulakshmi.(2015). Food Processing and Preservation Paperback, Publisher: newagepublishers; First edition (1 January 2006),ISBN-10: 8122412831,ISBN-13: 978-8122412833.

10. G. Subbulakshmi.(2015). Food Processing and Preservation Paperback, Publisher: newagepublishers; First edition (1 January 2006),ISBN-10: 8122412831,ISBN-13: 978-8122412833.

11. Iain Davidson.(2018).Biscuit, Cookie and Cracker Production,1st Edition,eBook ISBN: 9780128155806,Paperback ISBN: 9780128155790,Imprint: Academic Press,Published Date: 12th July 2018.

12. J. Scott Smith and Y. H. Hui : Food Plant Sanitation and Quality Assurance, First published: 06 July 2004,https:// doi.org/10.1002/9780470290118.ch7.

13. James G. Brennan and Alistair S. Grandison. (2011).Food Processing Handbook, 2 Volume Set 2nd Edition, Publisher: Wiley-VCH; 2 edition (December 19, 2011),ISBN-10: 9783527324682,ISBN-13: 9783527324682,ASIN: 3527324682.

14. James G. Brennan and Alistair S. Grandison. (2011).Food Processing Handbook, 2 Volume Set 2nd Edition, Publisher: Wiley-VCH; 2 edition (December 19, 2011),ISBN-10: 9783527324682,ISBN-13: 9783527324682,ASIN: 3527324682.

15. Jason D Ellis and Susan Arendt.(2010).Varying Influences of Motivation Factors on Employees' Likelihood To Perform Safe Food Handling Practices Because of Demographic Differences, Journal of food protection 73(11):2065-71 · November 2010,DOI: 10.4315/0362-028X-73.11.2065.

16. John Ehiri and George P. Morris : Hygiene training and education of food handlers,Article in Ecology of Food and Nutrition 35(4):243-251 · December 1996,DOI: 10.1080/03670244.1996.9991494.

17. John Salazar,Hea-Ran Ashraf,Miriam Tcheng .(2008).Food Service Employee Satisfaction and Motivation and the Relationship with Learning Food Safety, Published online: 23 Sep 2008,Journal, Journal of Culinary Science \& Technology

18. Karla Longrée and Gertrude Armbruster :Quantity Food Sanitation, 5th Edition, 1996,ISBN-13: 9780471596608,ISBN-10: 0471596604.

19. Marriott, Norman, Schilling, Wes, Gravani, Robert B. Principles of Food Sanitation, 6th Edition, SBN 978-3-31967166-6.

20. Marriott, Norman: Essentials of Food Sanitation, Copyright 1997 Springer Science, ISBN 978-1-4615-6045-6eBook ISBN 978-1-4615-6045-6,DOI 10.1007/978-1-4615-6045-6 ,Softcover ISBN978-0-412-08011-1.

21. Michael M Cramer: Food Plant Sanitation: Design, Maintenance, and Good Manufacturing Practices Article · January 2006,DOI: 10.1201/9781420005943.

22. Muhammad Shehbaz.(2016), Journal Food Process Technol 7:559. doi:10.4172/2157-7110.1000559 Published Date: February 02, 2016.

23. Paul Besselingand Elizabeth Montes Saavedra.(2015).Hazard and risk analysis in food processing Second,Publisher: CreateSpace Independent Publishing Platform; Second Edition edition (September 9, 2015),ISBN-10: 1517297583,ISBN-13: 978-1517297589. 
24. Paul Besselingand Elizabeth Montes Saavedra.(2015).Hazard and risk analysis in food processing Second,Publisher: CreateSpace Independent Publishing Platform; Second Edition edition (September 9, 2015),ISBN-10: 1517297583,ISBN-13: 978-1517297589.

25. Paul Sv. (2013).Safety Management System And Documentation Training Programme Handbook, Publisher: Cbs 2013,ISBN: $9788123923444,8123923449$.

26. Saccaro Joseph A. (1994).Developing Safety Training Programs: Preventing Accidents and Improving Worker Performance through Quality Training 1st Edition, ISBN: 9780471285212, 0471285218.Publisher: Wiley; 1 edition (August 24, 1994).

27. Sara E. Mortimore and Carol A. Wallace.(2015), Introduction to HACCP,First published: 11 March 2015,https:// doi.org/10.1002/9781118427224.ch1.

28. Satish Y. Deodhar.(2003).Motivation for and Cost of HACCP in Indian Food Processing Industry (2003).

29. Sivasankar.(2002):Food Processing and Preservation Paperback, Publisher: Prentice Hall India Learning Private Limited (2002),ISBN-10: 8120320867,ISBN-13: 978-8120320864.

30. Tara Paster (2006) : The HACCP Food Safety: Training Manual Paperback, Publisher: John Wiley \& Sons (17 October 2006),ISBN-10: 0471784486,ISBN-13: 978-0471784487.

31. Theodoros Varzakas and Constantina Tzia.(2015). Handbook of Food Processing: Food Safety, Quality, and Manufacturing Processes, CRC Press Published October 23, 2015, ISBN 9781498721776 - CAT\# K25600.

32. V Ravishankar Rai, Jamuna A Bai.(2017), Food Safety and Protection 1st Edition Publisher: CRC Press; 1 edition (September 20, 2017),ISBN-10: 1498762875,ISBN-13: 978-1498762878.

33. William D. Marler.(2005). Marler contributes to motivating factors effecting in Food Safety News and Food Poison in Journal Law Science, Published, and May 20, 2005

34. William R. Griffin and Bruce Jackson: Food Service: Health, Sanitation, and Safety Lslf Edition,ISBN-13: 9780960105441.

Citation: G. Ramu, Prof. D. Sreeramulu, Dr. Rambabu Lavuri, The Employees Perception of Food Safety Practices in select food companies, vol 6, no. 1, 2020, pp. 1-8.

Copyright (c) 2020 G. Ramu, et al. This is an open access article distributed under the Creative Commons Attribution License, which permits unrestricted use, distribution, and reproduction in any medium, provided the original work is properly cited. 